Review: Some Recent Work on the Viability of Seeds

Source: Journal of Ecology, Vol. 3, No. 1 (Mar., 1915), pp. 35-38

Published by: British Ecological Society

Stable URL: http://www.jstor.org/stable/2255297

Accessed: 26-06-2016 20:30 UTC

Your use of the JSTOR archive indicates your acceptance of the Terms \& Conditions of Use, available at

http://about.jstor.org/terms

JSTOR is a not-for-profit service that helps scholars, researchers, and students discover, use, and build upon a wide range of content in a trusted digital archive. We use information technology and tools to increase productivity and facilitate new forms of scholarship. For more information about JSTOR, please contact support@jstor.org.

Wiley, British Ecological Society are collaborating with JSTOR to digitize, preserve and extend access to Journal of Ecology 
these references had been collected at the end of the paper, but this is a small point. A comprehensive index to subjects is appended. Perhaps on the whole the paper gives the reader the impression that more is really known of the subject than is actually the case.

S. REGINALD PRICE.

\section{SOME RECENT WORK ON THE VIABILITY OF SEEDS}

(I) Darsie, M. L., Elliott, C., and Peirce, G. J. "A study of the germinating power of seeds.” Bot. Gaz., 53, 1914, pp. 101-136.

(II) Crocker, w., and Davis, w. E. "Delayed germination in seeds of Alisma plantago." Ibid., 58, 1914, pp. 285-321.

(III) Shull, G. H. "The longevity of submerged seeds." Plant World, 1 7, 1914, pp. 329-337.

(IV) Maxwell, H. “The longevity of seeds." Nature, 94, 1915, p. 592.

The capacity of some seeds for retaining their power of germination during more or less extended periods of time when buried in soil or submerged in water is a matter of obvious ecological importance. Various observers have shown that certain seeds are able to retain their vitality for many years under such conditions as dryness, moderate and uniform temperature, and partial or complete exclusion of oxygen. (For an account of earlier work on this subject, with a general consideration of the physiological problems presented by the viability of seeds, reference may be made to F. F. Blackman, "The longevity and vitality of seeds," New Phytologist, 8, 1909, pp. 31-36.) This capacity may prevent the extinction of a species under severe competition or temporarily unfavourable conditions, allowing it to take advantage of any event which reduces or removes the competition or restores conditions favourable to growth, and in many cases also forming an important condition for its successful introduction into new areas. Darwin recognised the importance of the durability of seeds in water as a condition favourable to the stocking of oceanic islands, and showed experimentally that some seeds could withstand the action of seawater for 140 days, so that if also able to float they might be carried over long stretches of ocean and lodged under favourable conditions for germination on some distant strand; while other investigators have shown that the time of submergenee might extend over a year (see III, below).

(I) The authors point out that hitherto tests of the vitality of seeds have depended upon the percentages of actual germinations in prepared beds, and that though such tests are satisfactory in the case of seeds which germinate quickly, another method is desirable in cases where under the most favourable conditions weeks may elapse before germination. Peirce had suggested that by using silvered Dewar flasks as calorimeters the differences in the heats liberated by seeds of different ages might be used as indicators of age and germinating power, and the present investigation was undertaken in order to test this idea. The results show that there is a decrease in the amounts of heat liberated as the seeds increase in age, the heat yield and the germinating power diminishing from year to year ; moreover, the youngest seeds also respond most quickly to the influence of conditions favourable to germination and reach the maximum percentage of germination and maximum temperature sooner than older seed. It was also found that germinating seeds, like higher animals, have temperatures which may be considered "normal" or charac- 
teristic, and that if the seed under test did not show this temperature or one not far removed from it, one is justified in concluding that there is something wrong with it; if the temperature is abnormally high, this is due to bacteria or fungi also liberating heat, if abnormally low the seed itself is weak. If within a reasonable length of time there is no rise in temperature, or a rise which does not indicate a normal temperature for the species concerned, one may conclude that the seed will not germinate-the time which must elapse before such a conclusion is justified varies, of course, with the species, as does the normal temperature. The authors' results are illustrated in numerous tables and graphs, and every precaution appears to have been taken to guard against sources of error, and there seems little doubt that this simple and ingenious method of seed-testing gives valuable and accurate results. The fact that departures from the normal temperatures are accompanied by differences in the amounts of growth immediately following germination suggests, as the authors point out, the possibility that this may be true of the other stages in the life of the plant, as in the case of the higher animals.

(II) It was found by Müller and by Ludwig that the seeds of some aquatic plants do not germinate without first being desiccated, while Guppy and Ostenfeld found that passage through the alimentary canal of birds greatly improves the germination of the seeds of various water-plants. Fischer found that acids and bases arouse many seeds of water-plants from their dormancy, but his conclusion that the efficacy of these reagents was due to their action on the embryo itself was shaken by Crocker's observation that water-plant seeds germinated readily in distilled water when the seed coats were broken or removed, and by Ewart's observation that the seeds of Sagittaria germinated readily after abrasion with sand-paper. Ewart also found that the effect of the acid or the base is not counteracted by the application of a sufficient amount of the other to neutralise it. In order to clear up these questions the authors have made a thorough investigation of the seeds of Alisma plantago, dealing with the structure and microchemistry of the seed-coat, the water relations of the coat and embryo, the effect of acids on the rate of intake of water by the embryo, turgor imbibition and growth elongation of the embryo, elasticity of the seed-coat, and oxygen pressure in relation to germination of the seed and to chlorophyll formation in the seedling. In their general discussion the authors point out that delayed germination of seeds is secured in various ways: by almost absolute exclusion of water by seed-coats, as in the hardseeded Leguminosae, etc.; by limiting the degree of swelling of the embryo by surrounding structures, as in Alisma and probably other water-plants; by reduction of oxygen supply below the minimum necessary for germination, as in Xanthium and other Compositae, some grasses, etc.; and perhaps by deficiency of salts. To these must be added delays due to embryo characters, as slowness of acid development in the hypocotyl of hawthorn, apple, and other Rosaceae. All these possibilities should be considered in enquiring into the mechanics of delayed germination, though various writers on this subject have assumed that injury to the seed-coat or the action of light must act as a stimulus on the embryo and that dormancy is therefore determined by the characters of the embryo alone. In the case of Alisma, the authors conclude that dormancy is due to the mechanical restraint of the seed-coat, which enables the seed to lie in water for years without germination; the chaffy pericarp of the achene plays no part in dormancy, and of the three layers of the seed-coat (outer single layer of brown cells, inner single layer of white cells, lining non-cellular pectic hemicellulose material) the outer seems to play no part in the delay, hence the effect must be attributed to one or both of the inner layers. As the intact fruit lies in water in the saturated condition, the embryo itself does not consummate more than perhaps one-fourth its possible imbibitional and osmotic swelling, and in this partly swollen state lies for years in water, restrained in its swelling 


\section{Some Recent Work on the Viability of Seeds}

by the seed-coat, against which it exerts a pressure of about 100 atmospheres. The air-dry seed, freed from the pericarp, when placed in water swells rapidly, increasing $40 \%$ of its air-dry weight in 2 hours and then showing a slow increase to $50 \%$, which is maintained constant even after long periods of soaking; a large part of the water absorption is due to the pectic and hemicellulose substances of the coat, especially the inner acellular layer. When the coat is removed, thus leaving the embryo more free to continue its imbibitional and osmotic swelling, the seed swells more rapidly, reaching about $60 \%$ of its air-dry weight in 2 hours and more than $100 \%$ in 20 hours; the swelling gradually passes into growth enlargement. The pectic substances of which the coat almost entirely consists are easily hydrolysed by weak acids and bases, which also change the water relations of these substances, as in the case of hydrophilous colloids generally. Acids increase slightly the imbibitional force of the embryo, while bases increase greatly the rate of elongation of the embryo. Apparently the effect of acids and bases on the germination of Alisma seeds is largely attributable to weakening of the seed-coat so that the imbibitional and osmotic swelling of the embryo is capable of breaking away the coat-cap at the larger end of the embryo, but they are possibly in part effective by increasing the force of the imbibitional and osmotic swelling-this gives a chemico-physical explanation which displaces the vague implications of the term "stimulus." The points of most obvious ecological interest are that the seeds of Alisma, and probably those of water-plants generally, are capable of lying in water for years in the imbibed condition without losing their vitality, whereas those of land-plants can only withstand storage for a relatively short time; and that the embryo of Alisma, at the expense of its stored food alone, is capable of more than $120 \%$ elongation in totil absence of oxygen, though for other phases of its development it requires free oxygen.

(III) In February, 1904, a flood carried away a dam on a creek opening into Cold Spring Harbour, Long Island, and the bed of a pond was laid bare for the first time in over 70 years. With the opening of spring there came into existence an abundant and varied covering of vegetation over nearly the entire pond-bed; the higher portions were quickly drained, dried hard, and fissured, and here the phanerogamic vegetation was sparse, but in the lower portions, which remained moist throughout summer, the carpet of vegetation became quite dense. More than 140 species were found, the great majority being annuals which must have developed from seeds lying in the mud. In view of the emphasis generally laid on the necessity of keeping seeds dry in order to maintain their vitality, the question arose whether the millions of seeds represented by this dense herbaceous carpet might have lain in the mud since the preceding autumn or even longer, or whether they must have been brought in by various distributing agents after, or at any rate not long before, the draining of the pond in spring. The seeds of 58 species were collected in November and placed in a large jar filled $2 \mathrm{dm}$. deep with soil from the pond-bed, water being added; the jar was kept cool, though rarely cold enough to freeze a little, throughout the ensuing winter. In March the water was drained off, exposing the seeds to abundant free oxygen, after 130 days of submergence; in 3 days numerous germinations occurred, and 24 species were represented among the seedlings. The author repeated the experiment next year with seeds of 22 species; one of the jars was turned out after a submergence of 18 months, another after 29 months, a third after more than 4 years, with the result that 11 species germinated in the last case. It was intended to keep the remaining jars for longer periods, but unfortunately the jars were mistaken for waste and the soil emptied on the grass outside the laboratory, where it remained unnoticed for a fortnight during which two sharp frosts occurred. The top part of the soil was then removed and placed on sterilised soil in seed-pans, and in a few days seedlings of Sivm cicutaefolium, Juncus bufonius, J. tenuis, Syntherisma 
sanguinalis and Trifolium sp. appeared. The two last might have been introduced into the soil after the jars were emptied, though Syntherisma had appeared in an earlier jar where no contamination had been possible. The rest of the seedlings must have developed from seeds which had been continuously submerged for nearly 7 years and then subjected in a presumably supersaturated condition to two sharp frosts, which may have killed other seeds that had retained their vitality during this long submergence. Since nearly half of the species gave germinations after a submergence of more than 4 years, and at least 3 species or $13.6 \%$ of those used in the experiment were still represented by viable seeds at the end of 7 years of continuous submergence, it is clear that no such strain is placed on the efficiency of the various distributing agents as was involved in the suggestion that the seeds which germinated in the bed of the drained pond must have been transported thither in the course of a few months at longest.

(IV) Referring to an abstract of the preceding paper, in which it was stated that this is a subject on which specific information is always desirable, the author of this note states that in 1862 a lake in Wigtownshire, Scotland, was drained, laying bare a number of ancient lake dwellings. The bottom of the lake was mostly covered with deep mud and peat, but across the centre of it lay a ridge of broken rock, now a dense jungle of Salix caprea, whereof the seeds were doubtless wind-blown. The author in 1909 explored these rocks, and in an open space in the thicket found the ground thickly covered among the stones with a thick carpet of Pyrola minor, a plant which apparently does not occur in the county, the nearest station being about 25 miles distant from the lake. He raises the question of the origin of the seeds that have produced this surprising crop of Pyrola minor, and mentions the possibility of their having lain dormant under the waters of the lake since the days when the primeval forest bordering the lake was cleared away and the land broken up for tillage, since the species probably once abounded in the county but has disappeared under the plough. 